Pacific Journal of Mathematics

NOTE ON EDELSTEIN'S ITERATIVE TEST AND SPACES OF
CONTINUOUS FUNCTIONS 


\title{
A NOTE ON EDELSTEIN'S ITERATIVE TEST AND SPACES OF CONTINUOUS FUNCTIONS
}

\author{
JACK BRyant and T. F. McCaBe
}

In this note a question posed by Nadler is answered. It is shown that if $X$ is a compact Hausdorff space that contains a sequence of distinct points that converge then there exists a linear contractive selfmap $f$ of $C(X)$ such that, for some $x$, the sequence of iterates $\left\{f^{n}(x)\right\}$ does not converge. In particular, the iterative test is not conclusive for $c$.

Our setting is a metric space $(X, d)$ and a contractive selfmap $f: X \rightarrow X$. In [1], Nadler introduces and motivates the following terminology: the iterative test (of Edelstein) is conclusive (for contractive maps) provided that if $f$ is a contractive selfmap of $X$ with a fixed point then, for all $x \in X,\left\{f^{n}(x)\right\}$ converges. Nadler shows that the iterative test is conclusive (ITC) for finite dimensional Banach spaces, but that the iterative test is not conclusive (ITNC) for the spaces $l_{p}(1 \leqq p<\infty)$ and $c_{0}$ (the space of sequences convergent to zero). The technique used there does not seem to apply directly to the space $c$ of convergent sequences, and part of Nadler's Problem 1 is exactly the question of whether $c$ has ITC.

LEMma 1. The iterative test is not conclusive for $c$.

Proof. Let $\left\{\alpha_{n}\right\}$ be an increasing positive sequence with (infinite) product $1 / 2$. Define $f: c \rightarrow c$ by $f\left(\left\{x_{n}\right\}\right)=\left\{y_{n}\right\}$ where

$$
\begin{aligned}
y_{1} & =0, \quad y_{2}=-y^{2}=\alpha_{1} x_{1}, \\
y_{2 n} & =-y_{2 n+1}=\frac{\alpha_{n}}{2}\left(x_{2 n-2}-x_{2 n-1}\right), \quad n=2,3, \cdots .
\end{aligned}
$$

Since $f$ is linear, $f$ has fixed point 0 , and it suffices to show $f$ is contractive at 0 ; if

$$
\left\{z_{n}\right\} \in c,\left\{x_{n}\right\} \neq 0, d\left(f\left(\left\{x_{n}\right\}\right), 0\right)=\sup \left\{\left|y_{n}\right|\right\}=\left|y_{n_{0}}\right|,
$$

since $y_{n} \rightarrow 0$. If $n_{0}=1$ or 2 then it is easy to see that

$$
d\left(f\left(\left\{x_{n}\right\}\right), 0\right)<d\left(\left\{y_{n}\right\}, 0\right) \text {. }
$$

If $n_{0}=2 k(k>1)$, we have

$$
\begin{aligned}
\left|y_{n_{0}}\right| & =\frac{\alpha_{k}}{2}\left|x_{n_{0}-2}-x_{n_{0}-1}\right| \leqq \frac{\alpha_{k}}{2}\left\{\left|x_{n_{0}-2}\right|+\left|x_{n_{0}-1}\right|\right\} \\
& \left.\leqq \alpha_{k} d\left(\left\{x_{n}\right\}, 0\right)<d\left(\left\{x_{n}\right\}\right), 0\right)
\end{aligned}
$$


Let $e_{k}$ be the sequence $\left\{\delta_{k n}\right\}=\{0,0,0, \cdots, 1,0, \cdots\}$ (1 in the kth coordinate). We have

$$
f^{j}\left(e_{1}\right)=\left(\prod_{i=1}^{j} \alpha_{i}\right)\left(e_{2 j}-e_{2 j+1}\right) .
$$

In particular, $d\left(f^{j}\left(e_{1}\right), 0\right)=\prod_{i=1}^{j} \alpha_{i} \rightarrow 1 / 2$, and so $\left\{f^{j}\left(e_{1}\right)\right\}$ does not converge. (If $\left\{f^{j}\left(e_{1}\right)\right\}$ converges, then, since $f$ is contractive, $f^{j}\left(e_{1}\right)$ must converge to the fixed point 0 of $f$.)

It is of definite interest that the map $f: c \rightarrow c$ constructed above is linear. It would seem to be easier to solve Nadler's Problem 1 (if a Banach space has ITC then it is finite dimensional) when restricted to linear maps.

Lemma 2. Let $Y$ be a normed space and let $X$ be a subspace of $Y$. Let $P$ be a projection of norm 1 from $Y$ onto $X$. Then if the iterative test is not conclusive for $X$, it is not conclusive for $Y$.

Proof. Let $f: X \rightarrow X$ be a contractive map with fixed point such that, for some $x_{0},\left\{f^{n}\left(x_{0}\right)\right\}$ does not converge. Define $g: Y \rightarrow Y$ by $g=f \circ P$. Since $f$ is contractive and $\|P\|=1$, then $g$ is contractive. Also, $g^{n}\left(x_{0}\right)=f^{n}\left(x_{0}\right)$ (since $\left.P\left(x_{0}\right)=x_{0}\right)$, and so $\left\{g^{n}\left(x_{0}\right)\right\}$ does not converge.

If $X$ is a compact Hausdorff space with a convergent sequence of distinct points, a projection $P$ of norm 1 can be constructed from $C(X)$ onto a subspace that is linearly isometric to $c$.

Let $\left\{x_{n}\right\}$ be any sequence of distinct points of $X$ that converges and furthermore $x_{n} \rightarrow \bar{x}$. Let $P_{1}: C(X) \rightarrow c$ be defined as follows: if

$$
f \in C(X), P_{1}(f)=\left\{y_{n}\right\} \text { where } y_{n}=f\left(x_{n}\right) .
$$

Since $f$ is continuous $y_{n} \rightarrow f(x)$ and $P_{1}(f) \in c . \quad P_{1}$ is nonexpansive for

$$
\left\|P_{1}(f)\right\|=\sup _{n}\left|f\left(x_{n}\right)\right| \leqq \sup _{x \in X}|f(x)|=\|f\| \text {. }
$$

An isometric linear map $Q$ is now constructed from $c$ into $C(X)$ such that $P_{1} \circ Q(x)=x$. Let $\left\{U_{i}\right\}$ be a sequence of open sets such that $x_{i} \in U_{i}, U_{i} \cap U_{j}=\varnothing$ if $i \neq j$, and $\bar{x} \notin U_{i}$ for all $i$. For each $i$ define $f_{i}$ to be a function such that $f_{i}\left(x_{i}\right)=1, f_{i}\left(X-U_{i}\right)=0$ and $0 \leqq f_{i}(x) \leqq 1$ for all $x$. If $\left\{y_{n}\right\} \in c$ and $y_{n} \rightarrow y$ then define $Q\left(\left\{y_{n}\right\}\right)=f$ where

$$
f(x)=\sum_{n=1}^{\infty} f_{n}(x)\left(y_{n}-y\right)+y \text {. }
$$

It is easily verified that $f$ is continuous, $f\left(x_{i}\right)=y_{i}$ and $\|f\|=$ $\left\|\left\{y_{n}\right\}\right\|$. Hence $Q: c \rightarrow C(X)$ is a linear isometry and 


$$
\left(P_{1} \circ Q\right)\left(\left\{y_{n}\right\}\right)=P_{1}\left(\left\{y_{n}\right\}\right)=\left\{y_{n}\right\} \text {. }
$$

Define $P: C(X) \rightarrow C(X)$ as $P=Q \circ P_{1}$. Since $P_{1}$ is onto and $Q$ is an isometry then $\|P\|=1$ and $P$ is a projection, for

$$
P^{2}=Q \circ P_{1} \circ Q \circ P_{1}=Q \circ P_{1}=P \text {. }
$$

Thus $P$ is a projection of norm 1 from $C(X)$ onto $Q(c)$.

Combining this construction with Lemmas 1 and 2 we have:

THEOREM. Let $X$ be a compact Hausdorff space that contains an infinite sequence of distinct points that converge. Then the iterative test is not conclusive for $C(X)$.

In each of the above, there is a linear selfmap for which the iterative test fails.

\section{REFERENCE}

1. S. B. Nadler, Jr., A note on an iterative test of Edelstein, Canad. Math. Bull., to appear.

Received November 11, 1971.

TeXas A AND M UNIVERSity

COLLege Station, TX 77843

AND

PAN AMERICAN UNIVERSITy

EDINBURG, TX 78539 



\section{PACIFIC JOURNAL OF MATHEMATICS}

\section{EDITORS}

RICHARD ARENS (Managing Editor)

University of California

Los Angeles, CA 90024

R. A. BEAUMONT

University of Washington

Seattle, WA 98105

C. C. Moore

University of California

Berkeley, CA 94720

\section{J. DugundJI}

Department of Mathematics

University of Southern California

Los Angeles, CA 90007

R. Finn and J. Milgram

Stanford University

Stanford, CA 94305

\section{ASSOCIATE EDITORS}

\section{E. F. BECKENBACH}

B. H. NEUMANN

F. WoLF

K. YOSHIDA

\section{SUPPORTING INSTITUTIONS}

\author{
UNIVERSITY OF BRITISH COLUMBIA \\ CALIFORNIA INSTITUTE OF TECHNOLOGY \\ UNIVERSITY OF CALIFORNIA \\ MONTANA STATE UNIVERSITY \\ UNIVERSITY OF NEVADA \\ NEW MEXICO STATE UNIVERSITY \\ OREGON STATE UNIVERSITY \\ UNIVERSITY OF OREGON \\ OSAKA UNIVERSITY
}

\author{
UNIVERSITY OF SOUTHERN CALIFORNIA \\ STANFORD UNIVERSITY \\ UNIVERSITY OF HAWAII \\ UNIVERSITY OF TOKYO \\ UNIVERSITY OF UTAH \\ WASHINGTON STATE UNIVERSITY \\ UNIVERSITY OF WASHINGTON \\ AMERICAN MATHEMATICAL SOCIETY
}

The Supporting Institutions listed above contribute to the cost of publication of this Journal, but they are not owners or publishers and have no responsibility for its content or policies.

Mathematical papers intended for publication in the Pacific Jaurnal of Mathematics should be in typed form or offset-reproduced, (not dittoed), double spaced with large margins. Please do not use built up fractions in the text of your manuscript. You may however, use them in the displayed equations. Underline Greek letters in red, German in green, and script in blue. The first paragraph or two must be capable of being used separately as a synopsis of the entire paper. Items of the bibliography should not be cited there unless absolutely necessary, in which case they must be identified by author and Journal, rather than by item number. Manuscripts, in triplicate, may be sent to any one of the editors. Please classify according to the scheme of Math. Reviews, Index to Vol. 39. All other communications should be addressed to the managing editor, or Elaine Barth, University of California, Los Angeles, California, 90024.

The Pacific Journal of Mathematics expects the author's institution to pay page charges, and reserves the right to delay publication for nonpayment of charges in case of financial emergency

100 reprints are provided free for each article, only if page charges have been substantially paid. Additional copies may be obtained at cost in multiples of 50 .

The Pacific Journal of Mathematics is issued monthly as of January 1966. Regular subscription rate: $\$ 7200$ a year (6 Vols., 12 issues). Special rate: $\$ 36.00$ a year to individual members of supporting institutions.

Subscriptions, orders for back numbers, and changes of address should be sent to Pacific Journal of Mathematics, 103 Highland Boulevard, Berkeley, California, 94708.

PUBLISHED BY PACIFIC JOURNAL OF MATHEMATICS, A NON-PROFIT CORPORATION

Printed at Kokusai Bunken Insatsusha (International Academic Printing Co., Ltd.). 8-8, 3-chome, Takadanobaba, Shinjuku-ku, Tokyo 160, Japan.

Copyrit (C) 1975 by Pacific Journal of Mathematics Manufactured and first issued in Japan 


\section{Pacific Journal of Mathematics \\ Vol. 69, No. $2 \quad$ June, 1977}

Carol Alf and Thomas Alfonso O'Connor, Unimodality of the Lévy spectral

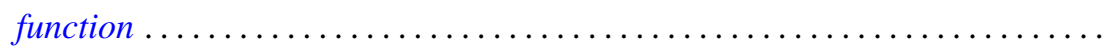

S. J. Bernau and Howard E. Lacey, Bicontractive projections and reordering of

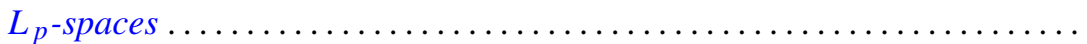

Andrew J. Berner, Products of compact spaces with bi-k and related spaces..... 303

Stephen Richard Bernfeld, The extendability and uniqueness of solutions of ordinary differential equations ...............................

Marilyn Breen, Decompositions for nonclosed planar m-convex sets ..........

Robert F. Brown, Cohomology of homomorphisms of Lie algebras and Lie

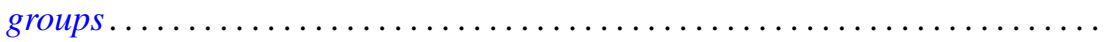

Jack Douglas Bryant and Thomas Francis McCabe, A note on Edelstein's iterative test and spaces of continuous functions ....................

Victor P. Camillo, Modules whose quotients have finite Goldie dimension ....... 333

David Downing and William A. Kirk, A generalization of Caristi's theorem with

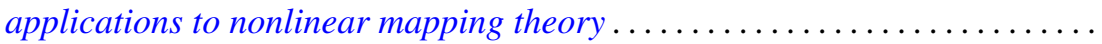

Daniel Reuven Farkas and Robert L. Snider, Noetherian fixed rings ...........

Alessandro Figà-Talamanca, Positive definite functions which vanish at

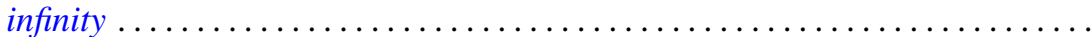

Josip Globevnik, The range of analytic extensions .................. 365

André Goldman, Mesures cylindriques, mesures vectorielles et questions de

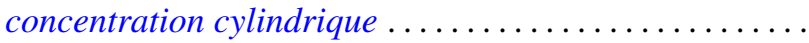

Richard Grassl, Multisectioned partitions of integers..........

Haruo Kitahara and Shinsuke Yorozu, A formula for the normal part of the

Laplace-Beltrami operator on the foliated manifold .... .

Marvin J. Kohn, Summability $R_{r}$ for double series .........

Charles Philip Lanski, Lie ideals and derivations in rings with involution ..

Solomon Leader, A topological characterization of Banach contractions . .

Daniel Francis Xavier O’Reilly, Cobordism classes of fiber bundles . .

James William Pendergrass, The Schur subgroup of the Brauer group . .

Howard Lewis Penn, Inner-outer factorization of functions whose Fourier series

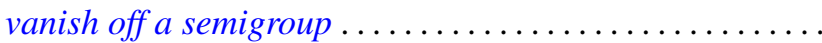

501

William T. Reid, Some results on the Floquet theory for disconjugate definite

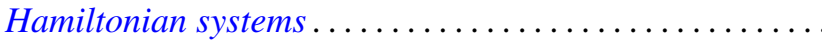

Caroll Vernon Riecke, Complementation in the lattice of convergence

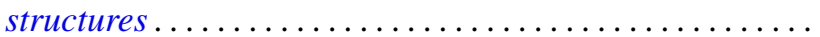

Louis Halle Rowen, Classes of rings torsion-free over their centers ......... 527

Manda Butchi Suryanarayana, A Sobolev space and a Darboux problem ....... 535

Charles Thomas Tucker, II, Riesz homomorphisms and positive linear maps.... 551

William W. Williams, Semigroups with identity on Peano continua ........... 557

Yukinobu Yajima, On spaces which have a closure-preserving cover by finite 